\title{
What to tell the White House
}

\section{The new White House Science Council is only a pale shadow of the old President's Science Advisory Committee; it should stay that way.}

The King is dead; long live the King (or the Queen as the case may be)! Can this declaration, much cherished by historians keen to demonstrate the repetitivity of events, be applied to that curious political animal in the United States - the President's Science Advisory Committee? The committee (PSAC, pronounced pea-sack) was abolished in 1973 by President Nixon, as legend has it because it had become too uppish. Although many in the then administration, including even the Secretary of State, Dr Henry Kissinger, agreed with PSAC's most talkative members that anti-ballistic missile systems were then technically backward and always likely to be strategically ineffectual (and, for that reason, dangerous), the administration plainly did not want its negotiating position compromised by a bunch of fast and independently-talking academics, among whom members of PSAC were prominent. But now, after a decent interval, there is to be a science advisory council in the White House again (see page 637). PSAC having ceased to exist, it seems as if it has been necessary to reinvent it as the White House Science Council. Appearances, however, are misleading.

In its heyday, perhaps until the mid-1960s, PSAC was a remarkable institution. In many ways, it was a continuation into peacetime (made to seem threatening by the arrival of the first sputnik) of the camaraderie of the veterans of technological wars - the people who had set up radiation laboratories, Manhattan Projects and the like. PSAC in its early days was immensely influential because its members were influential, both in the academic community and with the government. PSAC seemed merely to have to wave its wand, and the federal government would agree that there should be a programme of curriculum development aimed at the improvement of science teaching in high schools, for example - ironically, the programme now finally dismantled in the Administration's budget for 1983. On other occasions, the committee lent powerful support, from outside the White House, to the executive functions of the Science Advisor as, for example, in the early 1960s when Dr Jerome Wiesner was battling with Mr McGeorge Bundy for an influence over United States policy on disarmament (and defence). Unlike most other advisory committees, PSAC seems not to have bothered to wait for a request for advice but would offer its opinions gratuitously, sometimes to people who did not want to hear. Always, PSAC gave the technical community in the United States the sense, but also the illusion, that there was an effective and publicly constituted channel by means of which account could be taken of raw technical opinion. What went wrong?

The doctrine that everything that President Nixon did must by definition be mistaken is a poor guide to the truth. While the Nixon administration may have been more afflicted by public disagreement about arms control policy than previous administrations, there is also something in the view that the virtues that made PSAC seem to the technical community to be exceedingly important were precisely those calculated to be a thorn in the flesh of the White House. The dilemma has been neatly described by Dr Edward J. Burger in his book Science at the White House, published last year. (For Professor Harvey Brooks's review, see Nature, 290,$635 ; 1981)$. Because many of the committee's pronouncements were unsolicited, they were not assured of the welcome they might otherwise have had. But when asked for its advice, PSAC would often provide its masters with an opinion which, even if entirely correct, could only seem to the embattled administrators to be unhelpful and even self-serving. Burger tells how the White House of 1970 , anxious to do "something big" about public health but unsure of what, was disconcerted by a PSAC panel's view that a rapid growth of the force of practising physicians was unnecessary but that more money should be spent on biomedical research. The question remains unanswered whether a more pointed commentary on the options before the administration might have headed off President Nixon's "war" on cancer.

Administratively, Dr Keyworth's latter-day version of PSAC may be an improvement on the original. Even from the narrow view of the technical community, there is a balance to be struck between the prestige and independence of the old committee and the possibility that its successor may be listened to more attentively. The "bring back PSAC" campaign of the past nine years has been unreflective about this point. And even if, in the months immediately ahead, the chief function of the new science council is to strengthen Dr Keyworth's own position in the White House, that in the long run can do no harm. It may also help that the President's Science Advisor will be the sole channel for communication between the new council and the Administration. $\mathrm{He}$, no doubt, is likely to be best placed to judge when this or that study can most effectively be put into circulation - and which had better be kept in a drawer. The other side of the coin is that the new council will not become a focus for the attention of the technical community, a legitimized whispering tube, and that even the members of the new council may from time to time suspect that they are being used.

The field of operations for the new council is less certain. From some remarks let slip in London last week, Dr Keyworth seems to think of the new council as a means of helping him solve some awkward administrative problems - making different uses of well-established national laboratories for example. But how? A high-level survey of the resources and capabilities of the national laboratories would benefit the whole technical community, even outside the United States, but Dr Keyworth seems to have more particular goals in mind. Does he want the committee to be his hatchet-man? Or, more machiavellian, does he hope that a committee which includes Dr Harold Agnew (once director at Los Alamos) and Dr Edward Teller (closely identified with Livermore) is bound to resolve the ancient dilemma of deciding which laboratory should go? The most obvious danger is that if the committee is too much used as a means of confirming administrative decisions, or as a means of sanctifying prejudices about what the national laboratories can and cannot accomplish, its reputation in the technical community will be unenviable.

Even without a single meeting to its credit, the composition of the new council cannot fail to excite prurient speculation. For the first time in almost a decade, the White House now has a science adviser who is not afraid to confess his enthusiasm for highenergy physics, and many of the members of the new council can be counted on the back him up. But should not Dr Keyworth be mixing in wider circles? The appointment of Dr Edward Teller to the council is similarly disconcerting. Nobody disputes Dr Teller's ingenuity or his zeal. That he should be thought of as a hawk is beside the point. But his inconsistency and intellectual impulsiveness are hardly assets for a new committee. 